Yuzuncu Y1l University
Journal of Agricultural Science
http://dergipark.gov.tr/yyutbd
Albert Ukaro OFUOKU*1, Oluwasen Ijeoma EKORHI-ROBINSON
Nigeria
Response to Integrated Poultry-Vegetable Farming Practice Advocacy in Delta State,
1,2Delta State University, Asaba Campus, Faculty of Agriculture, Department of Agricultural Economics and
Extension, PMB 95074, Asaba, Delta State, Nigeria
1https://orcid.org/0000-0003-1395-8114 2https://orcid.org/0000-0001-6771-6765
*Corresponding author e-mail: albertofuoku@gmail.com, ofuoku@yahoo.com, ofuoku@delsu.edu.ng

\section{Article Info}

Received: 23.07.2019

Accepted: 12.01.2020

Online Published 31.03.2020

DOI: 10.29133 /yyutbd.595732

\section{Keywords}

Adoption,

Food security, Integrated farming, Integration, Poultry and vegetable, Waste management.

\begin{abstract}
In response to climate change, poultry - vegetable integrated practice was introduced for the management of poultry wastes and to reduce pollution. The cost of chemical fertilizers and the health implications of consuming vegetables produced using chemical fertilizers has been a source of concern to health and nutrition stakeholders. In order to mitigate this problem, the use of organic fertilizers was advocated. This study was conducted to determine the response level poultry - vegetable integration farming practice among farmers in Delta State, Nigeria. The data for the study was elicited from 192 randomly selected registered poultry farmers, with the use of questionnaire and structured interview schedule. The data were analyzed with the application of descriptive statistics such as frequency counts, percentages and means derived from 4 - point Likert - type scale and 5 - point Likert scale. The hypothesis that the socioeconomic attributes of farmers do not contribute to their practice of poultry-vegetable integrated farming was tested with the application of regression model. The farmers had a mean age of 45.1 years and poultry farm size average of 5571 birds with mean household size of 6 persons and means farming experience of 23.5 years. Most of them subscribed to membership of farmers' groups had 2 times contact with extension agents monthly. Their responses to poultry - vegetable integrated farming was encouraging as they had adoption index of 0.51 . The problems they had ranged from high cost of inputs, pests and diseases infestation low market price to inadequate information. It is recommended that Delta Agricultural Procurement Agency be revived; extension agents should introduce integrated pest management and organic method of pests and diseases control: Marketing extension was also recommended.
\end{abstract}

\title{
Nijerya, Delta Eyaletinde Entegre Kümes Hayvanı Yetiştiriciliği-Sebze Tarımı Uygulaması Savunuculuğuna Yanıt
}

\section{Makale Bilgileri}

Geliș: 23.07.2019

Kabul: 12.01 .2020

Online Yayınlanma 31.03.2020

DOI: $10.29133 /$ yyutbd.595732

\section{Anahtar kelimeler}

Benimseme,

Gıda güvenliği,
Öz: İklim değişikliğine cevaben, kümes hayvanı atıklarının yönetimi ve kirliliğin azaltılması için kümes hayvancılığı-sebze tarımı entegre uygulaması başlatılmıştır. Kimyasal gübrelerin maliyeti ve kimyasal gübre kullanılarak üretilen sebzeleri tüketmenin sağllk üzerindeki etkileri, sağllk ve beslenme paydaşları için endişe kaynağı oluşturmuştur. Bu sorunu hafifletmek için organik gübrelerin kullanımı savunulmaktadır. $\mathrm{Bu}$ çalışma, Nijerya'nın Delta Eyaleti'ndeki çiftçiler arasındaki kümes hayvancılığı-sebze tarımı entegrasyonu uygulamalarının yanıt düzeyini belirlemek amacıyla yapılmıştır. Çalışmanın verileri, rastgele seçilen 192 kayıtlı kümes hayvanı yetiştiricisinden elde edilen 
Entegre tarım, Entegrasyonu, Kanatl ve sebze, Atık yönetimi. anket verileri ve yapılandırılmış görüşme programı kullanılarak elde edilmiştir. Verilerin, dörtlü ve beşli olarak hazırlanan Likert ölçekli sorunların ortalamaları ve yüzdesel dağılımları ile basit tanımlayıcı istatistikler şeklinde analiz edilmiştir. Çalışmada, çiftçilerin sosyoekonomik özelliklerinin kümes hayvancılığı-sebze tarımı entegre uygulamalarına katkıda bulunmadığı hipotezi regresyon modeli ile test edilmiştir. Çalışmada çiftçilerin yaş ortalaması 45.1 yıl; ortalama kümes hayvanı sayısı 5571; ortalama hane halkı büyüklüğü 6,0 kişi ve ortalama çiftçilik deneyimi 23.5 yıl olarak belirlenmiştir. Çiftçi örgütlerine üye olan üreticilerin büyük çoğunluğu ayda iki kez yayım servisleri ile iletişim halindedir. Kümes hayvancılığı - sebze entegre uygulamasına verdikleri cevaplar 0.51 benimsenme endeksine sahip oldukları için cesaret verici bulunmuştur. Sahip olunan problemler yüksek girdi maliyetlerinden, ilaç, hastalık, düşük piyasa fiyatları ve yetersiz bilgiye kadar geniş bir aralıkta değişim göstermektedir. Delta Tarımsal Satın Alma Ajansı'nın yeniden canlandırılması için yayım servislerinin zararlı yönetimi, zararlılarla ve hastalıklarla mücadelede organik yöntemlerin uygulanması ile pazarlama ile ilgili konularda bilgi verilmesi önerilmektedir.

\section{Introduction}

To ensure food security for a fast mounting global population estimated at 9.1 billion in 2050 and over 10 billion by the end of the twenty first century is a mammoth challenge for the present agricultural production system (UNPF, 2011). Dwindling average farm size and financial challenges for superior investment in agriculture as a result of 80 farm families that belong to small and medium farmer categories intensify the problem. To secure food and nutrition security for considerable population, productivity improvement may offer a fundamental way out. This entails the implementation of scientific agronomic practices and technologies that guarantee an increase the productive ability of established agricultural systems. Agronomic practices such as the liberal use of chemical fertilizers and pesticides for the period of the twentieth century improved productivity significantly but detrimental environmental degradation that go with increased costs of operation in agriculture prompted concerns about economic feasibility and sustainability.

Integrated farming system is considered as a cross-linked farming structure where farmers employ high-quality organic food and renewable energy. The key rule of such method is to shrink pollution and boost income by combining diverse types of farming. For instance, we can speak about fields that are tilled by animals, pies are capable being employed to excavate the earth in preparation for sowing, and animal manure (like cow waste) can be utilized to fertilize the soil for production of crops and boost harvest, birds can be utilized in vineyards and gardens to get rid of branches from decayed fruits and weeds; they as well aid fertilization of the soil. Numerous animals are capable of forming a source of cheap fertilizers that are capable of being put into reasonable utility on the farm, they eat and digest lots of food with valuable enzymes that do not lose their nutrients following defecation. Reward of integrated farming system are that such farming system improves production in order to meet the demands of Nigerian population, appropriate recycling of waste and associated substances raises the earnings of farmers; strengthening of crops growth make the most of income in relation to locale, time and efforts. Soil remains fertile for a long period as a result of the proper use of organic waste while most of the waste transformed has a worth when utilised within the structure of the integrated system.

Integrated farming system ensures sustenance of income. This implies that within a year it will be feasible to create profit regularly from diverse agricultural sectors with separate seasons. The major thing is to opt for the correct spheres for work so that there are no inactive times and pauses without earnings. The utility of by-products makes the system more steady and the potential of the soil, which acts as an industrial base, is preserved. One is capable of producing every kind of healthy foods on just a single farm; the products will be entirely enhanced with a variety of valuable nutrient components that the human body requires. This system of improving agricultural productivity is totally safe and environmentally friendly. The quantity of waste becomes minimized. In such a situation, there is small rotting waste and effluence in contrast to other methods of production. Excessive use of chemical fertilizers and pest control agents is not needed, in order to have clean water, soil and air. Another effect 
of the use of chemical fertilizers can be found to contribute to the problem that gave rise to climate change.

Climate change forms one of the most challenging factors in contemporary time (Antti, et al., 2015). It is has become such a serious problem globally as a result of its causes and effects and the needed solutions to it (Thiele, 2013). Thus, climate change has various ways it influences every function of the social system, and that include farming and agriculture, and climate policy makers are under obligation to set fresh goals for strategies to produce and consume food (Almås et al., 2011; Paarlberg, 2013). In the situation of the food system, a lot of fresh policy ideas and innovative ideas and technologies have been offered as to how farms, among others might shrink their susceptibility to the risks resulting from changing climatic conditions. The food systems have the capability of reducing dangerous emissions and promote sustainable development in diverse ways, such as reducing waste. It has the capacity to even utilize waste to create up-to-the-minute innovative products (Stuart, 2009). The development of this type has varied influences on agriculture and production of food (Renwick and Wreford, 2011). However, the triumph of these climate policy implementations dependent on the universal social acceptance of the policy goals and climate change mitigation and adaptation measures (Antti, et al., 2015) one of which is the encouragement of poultry-vegetable integrated farming.

Environment-friendly farming as is the case of poultry-vegetable integrated farming have been considered by Karaturhan et al. (2018) as a farming practice that minimizes the negative effect of human activities on the environment while encouraging soil protection. In another study in China, Rehman et al. (2016) found that organic fertilizer encouraged soil microbial biomas concentrations than inorganic fertilizer. This implies that organic fertilizer creates and enhances strong soil community structure than inorganic fertilizer. This has implications for soil fertility level. Parveen and Nazhat (2015) assert that people prefer natural foods and their agricultural production techniques and as observed by Karaturhan and Uzmay (2018), this is indicative of the factors that motivate the adoption of organic farming among female farmers in Turkey.

Growth in population, urbanization and growth in earnings in developing nations are powering a considerable worldwide boost in the demand for food of animal source, while also fanning the fire of rivalry involving crops and livestock (ever-increasing cropping areas and plummeting rangelands). Not only that the current livestock pressure is too high for the capability of obtainable production resource, but it is also worsening environmental challenges. Thus, while it is a necessity to meet up with the demand of consumers, improve nutrition and express income growth opportunities to those who require them most, it is as well essential to lessen environmental strain.

Conventional agriculture is acknowledged as the source soil and pasture degradation for the reason that it involves thorough tillage, in particular if practiced in areas of insignificant productivity. Technologies and management schemes that are capable of improving productivity need to be developed. At the same time, it is necessary to fathom ways of preserving the natural resource base. Within this structure, an integrated crop-livestock farming system symbolizes a key solution for enhancing livestock production and conserving or protecting the environment in the course of careful and professional use of resources.

Diversified farming system involves enterprises components such as crops and livestock that coexist separately from each other (FAO, 2001) In this case, integrating crops and livestock offers to principally reduce risk as well as to recycle resources. In an integrated system, crops and livestock interrelate to generate a synergy, with recycling allowing the utmost utility of obtainable natural assets. Crop waste or left-over is useful for animal feed, while livestock and livestock by-product production and processing have the capacity of improving agricultural productivity by increasing nutrients that perk up soil fertility, while reducing the employment of chemical fertilizers. A serious integration of crops and livestock is more often than not, seen as a step forward, but a matter of necessity for small-scale farmers to have adequate access to inputs, assets and knowledge to be able to manage this system in a way that it will be economically and environmentally sustainable over the long of time period.

The vegetables mainly grown in Africa, particularly the tropical region include Amaranthus, Celosia, Cucumis, Hibiscus, Talinum, Solanum and Corchorus with onion, tomato, okra, pepper, amaranthus, pumpkins, carrot, melon, and Jute (Ibeawuchi et al., 2015). However, vegetables are by and large linked with a variety of constraints especially in the production facet. The utilisation of inorganic fertilizers on farms is known to lead to problems of serious soil destruction, enhances soil acidity level and nutrient imbalance and final consequence is low output, but the utilisation of organic fertilizer helps to protect the soil from the afore mentioned adverse effects. 
Vegetable cultivation is dominated by females while poultry farming is male dominated. Adebayo and Adekunle (2016) also reported that the gender of an individual can influence the type and quality of work carried out by the individual. Vegetable cultivation is dominated by females while poultry farming is male dominated. Adebayo and Adekunle (2016) also reported that the gender of an individual can influence the type and quality of work carried out by the individual. Adebayo and Adekunle (2016) argue that most farmers in Kwara State, Nigeria administer organic fertilizer to their vegetables and the resultant effects of the use are observable. However, with this advocacy, the gender relations are no longer important among this group of farmers. This is so because poultry farmers are expected to include vegetable farming to their enterprise as vegetable farmers are also to add poultry farming to their enterprise.

The constraints to the use of organic fertilizer were identified by Adebayo and Adekunle (2016), Aderinoye-Abdulwahab, and Salami (2017) as offensive odour, its bulky nature, difficulty involved in its transportation and doubtful efficacy of it among the farmers are the constraints militating against the utilization of organic fertilizer. Furthermore, inadequate space restricts use of organic fertilizer. Lower output that result from the application of organic fertilizer is a challenge its usage. This may be an advantageous and disadvantageous at the same time since while the slowness may reduce present output, the long enduring effect of organic fertilizer because of its slow release of minerals is capable of decreasing future cost of production and enhance future output (Alimi et al., 2006). The pollution emanating from livestock rearing is thus a serious problem because most of them are usually sited around residential areas (Obi et al., 2016). Air pollution includes odours emanating from cages resulting from the digestion process of livestock wastes; the putrefaction process of organic matter in manure; animal urine, and/or from redundant foods (Obi et al., 2016).

The usage of organic fertilizer is determined, however by some socioeconomic variables in spite of the afore said constraints. These socioeconomic variables include age, formal educational level and years of farming experience that have been found to have positively and significantly influenced level of adoption of organic fertilizer (Adebayo and Adekunle, 2016). Despite the importance of agriculture for economic development, agriculture has yet to perform as an engine of growth in many developing countries - especially sub-Saharan Africa (Byerlee, de Janvry and Sadoulet, 2009). Agricultural yields have only shown slight increases in sub-Saharan Africa and Latin America since the 1960s, despite the development of important agricultural innovations during that time. Yet data on adoption of improved agricultural technologies paint a picture of low levels of adoption in developing countries, particularly sub-Saharan Africa. Broadly speaking, technology is the relationship between inputs and outputs. In this context, therefore, technology adoption is defined as the use of new tools or techniques that relate inputs to outputs and the allocation of inputs (Foster and Rosenzweig, 2010). The need to adopt improved integrated poultry-vegetable production technologies in order to make their task of waste management easier, ensure a sustained and efficient production of vegetables, enhance economic development and as well boost agricultural production becomes imperative for farmers. Ofuoku et al. (2008); Ofuoku (2013) suggest that the level of adoption of agricultural technologies is an index of extension communication effectiveness. Extension service has crucial role to play in poultry waste management through integration of vegetable production. This is expected to be or have been done through their connection between researchers and farmers. In the absence of extension services, most research efforts would be a nullity (Adebolu and Ikotum, 2001). The level of adoption of poultry - vegetable integrated farming is an index of the effectiveness of extension services. It is against this background therefore, that this study was focused on the adoption of integrated poultry-vegetable production technology by farmers in Delta State, Nigeria. The main objective of the study was to find out the determinants the response to integrated poultry-vegetable production technology by farmers in Delta State, Nigeria. Specifically, the project seeks to examine the socio-economic characteristics of the respondents; determine the level of adoption of integrated poultry - vegetable farm practice; ascertain the reasons why the integrative practice; identify factors militating against the adoption of integrated poultryvegetable practice. It was hypothesized that farmers' socioeconomic attributes do not contribute to the practice of poultry-vegetable integrated farming. 


\section{Material and Methods}

\subsection{Study area}

Delta State, the study areas is situated between longitude $5^{0}, 00^{\prime}$ and $6^{0}, 45^{\prime}$ east of Green-Wich Meridian; and latitude $5^{0} 00^{\prime}$ and $6^{0} 30^{\prime}$ north of the Equator (Ministry of Land and Survey, 1991). It shares boundaries with Edo State by the north; Bayelsa States and Atlantic Ocean at the South; Anambra and Imo States at the east, and with Ondo State in the West (Delta State Ministry of Land and Survey, 1991). It consists of 25 local government areas and has a total land area of 17698 square kilometers and a population of 2570181 people (NPC, 2006).

Poultry farming is a thriving business in the state as the climatic conditions encourage poultry farming. Hence the large number of commercial poultry farms in the state. The state is demarcated South, Central and North Agro-ecological Zones based on its vegetative cover. These zones are named by the Delta State Agricultural Development Programme (DTADP) thus, Delta State, Central and North Agricultural Zones respectively.

\subsection{Population and sampling method}

The population of this study included all the poultry farmers registered with DTADP in the three agricultural zones. The DTADP (2008) grouped poultry farms according to farm size (population of birds reared) in to:

Small scale $=1000-4999$ birds

Medium scale $=5000-7999$ birds

Large scale $=8000$ and above birds

Farmers are accordingly classified as such.

Random sampling procedure was applied while selecting 192 respondents from among the poultry farmers registered the three DTADP zonal offices on the basis of $10 \%$ from each class in each zone as follows in Table 1. This was done to create room for equitable representation in the study sample.

Table 1. Selection of sample size for the study.

\begin{tabular}{lll}
\hline \multicolumn{1}{c}{ Zone } & No of Poultry Farmers & No Selected (10\%) \\
\hline Delta North Agricultural zone & 383 & 38 \\
Small - scale & 256 & 26 \\
Medium scale & 141 & 14 \\
Large scale & & \\
Delta Central Agricultural Zone & 535 & 54 \\
Small - scale & 352 & 35 \\
Medium scale & 216 & 22 \\
Large scale & & \\
Delta South Agricultural Zone & 15 & 2 \\
Small - scale & 6 & 1 \\
Medium scale & 0 & 0 \\
Large scale & 1904 & 192 \\
\hline Total & & \\
\hline
\end{tabular}

\subsection{Data collection}

Data for the study were collected with the use of questionnaire and structured interview schedule from formally educated and farmers who had no formal education respectively. The data were collected by agricultural science teachers in secondary schools in the farmers' zones. 


\subsection{Data analysis}

The data collected were treated with descriptive statistic such as frequency counts, percentages and means derived from 4 - point Likerts - type scale and 5 - point Likert's scale adoption mean was computed by dividing the adoption score with the number of respondents. SPSS was used to run the data analysis. As adapted from Ofuoku. (2017); Hamidu (2006), the grand adoption mean was calculated by dividing the total adoption mean by the number of poultry - vegetable integration dividing the grand adoption mean by the number of stages in adoption process. Deressa et al. (2009) adopted linear regression in testing the influence of socioeconomic characteristics of farmers on adoption of adaptation measures to climate change and he chose this model because the dependent variable- adoption is measured with continuous data. In this study, it is adopted because adoption level of adoption is measured with continuous data. Hence the hypothesis was tested with the use of linear regression model, specified as follows:

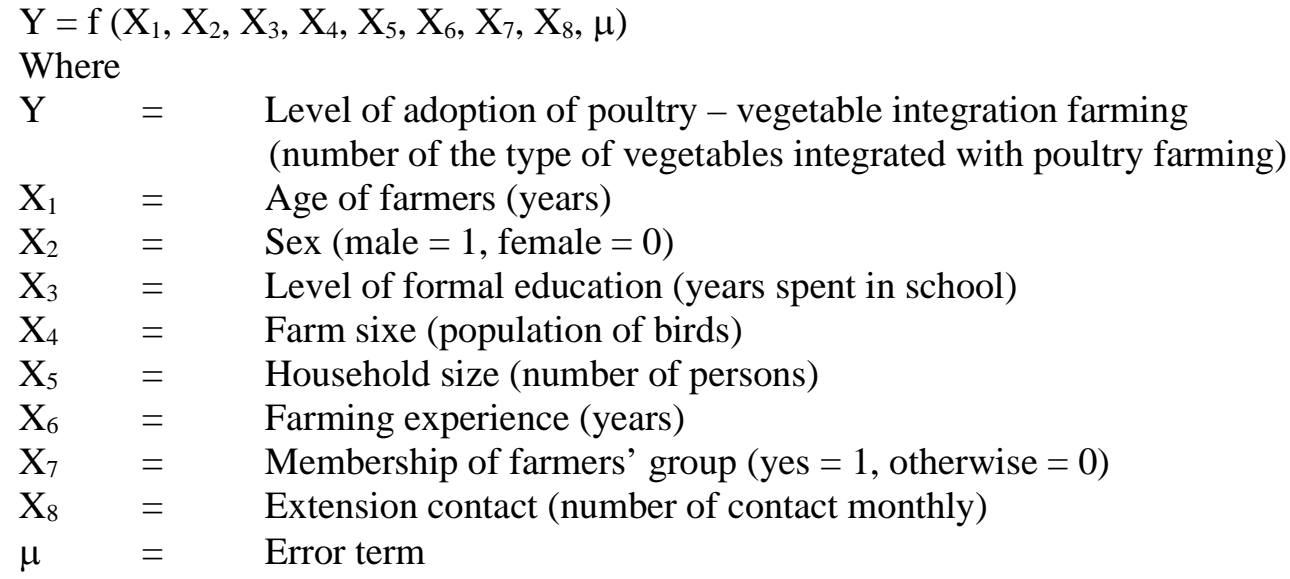

\section{Results}

\subsection{Socioeconomic characteristics of poultry farmers}

The poultry farmers had an average age of 45.1 years (Table 2). Many (44.27\%) of them were in the age bracket of $41-50$ years, while $21.88 \%$ were $31-40$ years of age. Most (68.23\%) were males and $31.77 \%$ were females. This implies that poultry farming in the study area is dominated by men. That most of them were in the age bracket of 31-50 years means that the poultry of farmers were young and energetic enough to handle the challenges involved in poultry management.

Most (68.23\%) were married while 39.58\% were single, divorced or widowed. This is indicative of the fact that most of them had obligations to cater for the needs of their families. Most of them had one level of formal education or the other as $64.58 \%$ of them had tertiary education, and $14.06 \%$ had secondary education, while $10.94 \%$ had primary education. Madukwe (1995), Ofuoku et al., (2008) found education to be one of the crucial variables in adoption of ideas and technologies among farmers.

With respect to farm size, some (29.17\%) had farm sizes of 2000 and below number of birds; 14.58 had farm sizes of between 2001 and 4,000 birds, 8.33\%, 4001-5000 birds; 14.06\%, 5001-6000 birds; $13.02 \%, 6001-7000$ birds; $10.94 \%$, 7001-8000 birds; while $9.90 \%$ had above 8,000 birds. DTADP (2008) classified farmers with 5000 and below population of birds as small scale poultry farmers, 50018000 birds as medium scale farmers and above 8000 birds as large scale farmers. The mean farm size was 5571 implying that most of the poultry farmers were operating on small scale. The farmers had a mean household size of 6 persons. This is an indication that the HHs were large. This is not unconnected with the high bird rate nurtured by the culture of Africans and Nigerians in particular.

Many (40.63\%) had farming experience of 1-10 years; some (22.92\%) had poultry farming experience, with overall mean farming experience of 23.5 years. Most (71.88\%) subscribed to poultry farmers' group membership. Ofuoku and Urang (2012), Ofuoku (2013) found that farmers join farmers' groups for the purpose of accessing extension service, cheap inputs and exchange of knowledge and 
ideas. Most (54.17\%) of them had extension contact of 2 times monthly. This is just a little of half of the population of the study. This is attributable to absenteeism in meetings with extension agents.

Table 2. Socioeconomic characteristics of poultry farmers.

\begin{tabular}{|c|c|c|c|}
\hline Variables & Frequency & Percentage (\%) & Mean \\
\hline \multicolumn{4}{|l|}{ Age } \\
\hline $20-30$ & 30 & 15.63 & \\
\hline $31-40$ & 42 & 21.88 & \\
\hline $41-60$ & 85 & 44.27 & $45.1 \mathrm{yrs}$ \\
\hline $51-60$ & 23 & 11.98 & \\
\hline 61 and above & 12 & 6.25 & \\
\hline \multicolumn{4}{|l|}{ Sex } \\
\hline Male & 131 & 68.23 & \\
\hline Female & 61 & 31.77 & \\
\hline Marital status & 116 & 60.42 & \\
\hline Single & 76 & 39.58 & \\
\hline \multicolumn{4}{|c|}{ Level of formal education } \\
\hline No formal education & 20 & 10.42 & \\
\hline Primary education & 21 & 10.94 & \\
\hline Secondary education & 27 & 14.06 & \\
\hline Tertiary education & 124 & 64.58 & \\
\hline \multicolumn{4}{|c|}{ Farm size (Number of birds) } \\
\hline 2000 and below & 56 & 29.17 & \\
\hline $2001-4000$ & 28 & 14.58 & \\
\hline $4001-5000$ & 16 & 8.33 & \\
\hline $5001-6000$ & 27 & 14.06 & \\
\hline $6001-7000$ & 25 & 13.02 & \\
\hline $7001-8000$ & 21 & 10.94 & \\
\hline Above 8,000 & 19 & 9.94 & \\
\hline \multicolumn{4}{|c|}{ Household (HH) size (Number of persons) } \\
\hline $1-3$ & 30 & 15.63 & \\
\hline 4-6 & 116 & 60.42 & 6 persons \\
\hline 7-9 & 35 & 18.23 & \\
\hline Above 9 & 11 & 5.73 & \\
\hline \multicolumn{4}{|c|}{ Farming experience (years) } \\
\hline $1-10$ & 78 & 40.63 & \\
\hline $11-20$ & 44 & 22.92 & \\
\hline $21-30$ & 21 & 10.94 & $23.5 \mathrm{yrs}$ \\
\hline $31-40$ & 25 & 13.02 & \\
\hline Above 40 & 24 & 12.50 & \\
\hline \multicolumn{4}{|c|}{ Membership of farmers groups } \\
\hline Yes & 138 & 71.88 & \\
\hline No & 54 & 28.13 & \\
\hline \multicolumn{4}{|c|}{$\begin{array}{l}\text { Extension contact monthly (Number of } \\
\text { times) }\end{array}$} \\
\hline 0 & 0 & 0 & \\
\hline 1 & 37 & 19.27 & \\
\hline 2 & 104 & 54.17 & \\
\hline 3 & 31 & 16.15 & \\
\hline 4 & 20 & 10.42 & \\
\hline
\end{tabular}




\subsection{Level of adoption of poultry-vegetable integrated farmer}

There were high levels of adoption of integration of poultry farming with all the recommended vegetables (Table 3). This is further confirmed by the grand adoption means of 4.05 and adoption index of 0.81 . The adopting index of 0.81 implies that $81 \%$ of the poultry farmers already integrated poultry farming with the recommended vegetables.

Table 3. Adoption response of farmers on poultry-vegetable integrations.

\begin{tabular}{|c|c|c|c|c|c|c|c|}
\hline Integration & $\begin{array}{l}\text { Awareness } \\
1\end{array}$ & $\begin{array}{l}\text { Interest } \\
2\end{array}$ & $\begin{array}{l}\text { Evaluation } \\
3\end{array}$ & Trial 4 & $\begin{array}{l}\text { Adoption } \\
5\end{array}$ & Score & Mean \\
\hline $\begin{array}{l}\text { Poultry with Telferia } \\
\text { occidentalis }\end{array}$ & $20(20)$ & $32(64)$ & $35(105)$ & $41(164)$ & $64(320)$ & 673 & 3.51 \\
\hline $\begin{array}{l}\text { Poultry with Talinum } \\
\text { trinaugulare }\end{array}$ & $15(15)$ & $17(34)$ & $23(69)$ & 29 (116) & $108(540)$ & 774 & 4.03 \\
\hline $\begin{array}{l}\text { Poultry with } \\
\text { Amaranthus }\end{array}$ & $11(11)$ & $8(16)$ & $19(57)$ & $26(104)$ & $128(640)$ & 828 & 4.31 \\
\hline Poultry with Tomatoes & $5(5)$ & $10(20)$ & $14(42)$ & $21(84)$ & $142(710)$ & 861 & 4.48 \\
\hline Poultry with cucumber & $9(9)$ & $16(32)$ & $22(66)$ & 38 (152) & 107 (535) & 794 & 4.14 \\
\hline $\begin{array}{l}\text { Poultry with water } \\
\text { melon }\end{array}$ & $12(12)$ & $19(38)$ & 38 (114) & $43(172)$ & $80(400)$ & 736 & 3.83 \\
\hline
\end{tabular}

Cut-off score $=3.0$ ( $\geq 3.0$ high level of adoption; $<3.0=$ low adoption level

Grand adoption means $=4.05$

Adoption index $=0.81$

\subsection{Reasons for poultry-vegetable integrated farming}

Table 4 indicates that the reasons for poultry-vegetable integrated farming by the farmers included waste recycling (mean $=3.84$ ), creation of extra income (mean $=3.70)$, feed for birds (mean= 3.76) and source of food for the farm families (mean=3.94). This means that all the reasons informed their adoption of integrated poultry-vegetable farming. This is expected to solve the problem of waste management and earn them extra income.

Table 4: Reasons behind poultry-vegetable integrated farming.

\begin{tabular}{|c|c|c|c|c|c|c|}
\hline Reasons & $\begin{array}{c}\text { Strongly } \\
\text { agreed (4) }\end{array}$ & Agreed 3 & Disagree 2 & $\begin{array}{l}\text { Strongly } \\
\text { disagree (1) }\end{array}$ & Score & Mean \\
\hline Waste recycling & $162(648)$ & $30(90)$ & $0(0)$ & $0(0)$ & 738 & 3.84 \\
\hline $\begin{array}{l}\text { Creation of } \\
\text { extra income }\end{array}$ & 134 (536) & $58(174)$ & $0(0)$ & $0(0)$ & 710 & 3.70 \\
\hline $\begin{array}{l}\text { Feed for bird } \\
\text { Vegetable for } \\
\text { family }\end{array}$ & $146(584)$ & 46 (138) & $0(0)$ & $0(0)$ & 722 & 3.76 \\
\hline consumption & $181(742)$ & $11(33)$ & $0(0)$ & $0(0)$ & 757 & 3.94 \\
\hline
\end{tabular}

\subsection{Factors militating against adoption of poultry-vegetable integrated farming practice}

The important factors militating against poultry - vegetable integrated farming practiceincluded, in order of importance, high cost of pesticides and fungicides (97.40\%), Low market price of vegetables (94.79\%), pests and diseases infestation (90.10\%) and high cost of improved vegetable seeds (83.85\%) (Table 5). Inadequate information (19.79\%), though not common among the farmers, is a challenge to some of them. 
Table 5. constraints to adoption of poultry-vegetable integrated farming practice.

\begin{tabular}{lll}
\hline Constraints & Frequency & Percentage\% \\
\hline $\begin{array}{l}\text { High cost of improved seeds of } \\
\text { vegetables }\end{array}$ & 161 & 83.85 \\
$\begin{array}{l}\text { Pests and diseases infestation } \\
\text { High cost of pesticides and }\end{array}$ & 173 & 90.10 \\
fungicides & 187 & 97.40 \\
Inadequate of information & 38 & 19.79 \\
Low market price of vegetables & 182 & 94.79 \\
\hline
\end{tabular}

There were multiple responses.

\subsection{Contribution of farmers socioeconomic attributes of poultry farmers to practice of poultry- vegetable integrated farming practice}

Table 6 shows on $\mathrm{R}^{2}$ value of 0.683 which indicates that $68.3 \%$ of the variations in the practice of poultry-vegetable integrated farming practice were explained by the independent variables, captured in the models. Sex, formal education, household size, farming experience, membership of farmers' group and extension contact had significant relationship with the practice of poultry-vegetable integrated farming practice.

Sex $\left(\mathrm{X}_{2}\right)$ had a positive significant relationship with the practice of poultry-vegetable integrated farming at $1 \%$ level of significance. This implies that male poultry farmers are more likely to practice integration of poultry with vegetable farming.

Table 6. Estimation of the contribution of farmers' socioeconomic attributes to the practice of poultryvegetable integrated farming.

\begin{tabular}{llll}
\hline Variables & Coefficient & Error & t-ratio \\
\hline Constant & 2.2336 & 0.2736 & $13.1716^{*}$ \\
Age $\left(\mathrm{X}_{1}\right)$ & 0.1780 & 0.6610 & 0.1120 \\
Sex $\left(\mathrm{X}_{2}\right)$ & 0.1376 & 0.1146 & $7.7142^{*}$ \\
Formal education $\left(\mathrm{X}_{3}\right)$ & 0.2826 & 0.1825 & $2.5124^{* *}$ \\
Farm size $\left(\mathrm{X}_{4}\right)$ & 0.1698 & 0.4607 & 0.2731 \\
Household size $\left(\mathrm{X}_{5}\right)$ & 0.0320 & 0.0211 & $2.2008^{* *}$ \\
Farming experience $\left(\mathrm{X}_{6}\right)$ & -0.0372 & 0.0124 & $-2.9921^{*}$ \\
Membership of farmers group $\left(\mathrm{X}_{7}\right)$ & -0.0997 & 0.0549 & $-2.0347^{* *}$ \\
Extension contact $\left(\mathrm{X}_{8}\right)$ & 0.0645 & 0.0344 & $2.2921^{* *}$ \\
\hline
\end{tabular}

$\mathrm{R}^{2}=0.681, \mathrm{R}^{2}$ adjusted $=0.661$, significant at $1 \%$, ${ }^{* *}$ significant at $5 \%$.

Formal education $\left(\mathrm{X}_{3}\right)$ significantly and positively contributed to the practice of poultryvegetable integrated faming $(\mathrm{P}<0.05)$. This means that a unit increase in formal education level would lead to a unit increase in the practice of the integration of poultry and vegetable farming. Household size $\left(\mathrm{X}^{5}\right)$ also significantly and positively contributed to the decision to practice poultry-vegetable integrated farming $(\mathrm{P}<0.05)$. A unit increase in household size would likely lead to a unit increase in the practice of the integrated farming.

Farming experience $\left(\mathrm{X}_{6}\right)$ significantly, and negatively related with the practice of the integrated farming $(\mathrm{P}<0.001)$. The negative sign born by the coefficient means that increased farmers' experience lowers the decision not to practice the integration of poultry with vegetable farming. Membership of farmers' associatios $\left(\mathrm{X}_{7}\right)$ significantly contributed to the integrated farming practice $(\mathrm{P}<0.05)$. However the coefficient bore a negative sign. This implies that subscription to membership of farmers' group has the likelihood to towards not adopting integrated poultry-vegetable farming practice. Extension contact (frequency of farmer - extension contact) $\left(\mathrm{X}_{8}\right)$ had a relationship with the practice of poultry-vegetable integrated farming among farmers $(\mathrm{P}<0.05)$, and the coefficient bore a positive sign. This indicates that increased contact of farmers with extension agents has the likelihood to raise the tendency to practice the integrated farming among poultry farmers. 


\section{Discussion and Conclusion}

That most of the farmers were young implies that they were energetic and were capable of carrying out the daily tasks involved in poultry business. Many young men now run poultry farming business as their parents have handed over the farms to them and only play advisory role because of old age (Ofuoku, 2013). The involvement of young men and women in poultry farming could also be attributed to the establishment of Youth Empowerment through Agriculture and Youth Agricultural Entrepreneurship Programme of the state government in the previous and current regimes. In the programme both male and female youths participated and it was established to empower young graduates for self employment. The involvement of these young adults in poultry farming indicates that the programme was a success.

Most of them subscribed to the membership of farmers' groups as a consequence of the poor ratio of extension officers to farm families. Extension-farmers contact are currently carried out in specialized groups because of the poor ratio of extension personnel to farm families in Nigeria. Agbamu (2005) observed that the ratio of extension agents to farm families started at 1:1000. Farmers groups form a clearing house for knowledge were farmers exchange ideas and knowledge among themselves and with extension agent.

The level of adoption of integrated poultry-vegetable farming practice was high among the poultry farmers. The encouraging adoption level is attributable to the efficacy of the innovation and the effectiveness of the communication between extension agents and the farmers. Ofuoku (2013) opines that the level of adoption of innovations is an index of the effectiveness of the communication process that conveys the innovation messages. The additional income they realize from the sale of vegetables is also a factor that has encouraged the high adoption level among the poultry farmers.

The reasons given by poultry farmers for adoption of the practice ranged from waste recycling, creation of extra income, feed for birds to additional source of food for the farm families. There was a period when poultry waste management was a problem. This was a result of the odour effect on the environment and not many crop farmers adopted poultry west as fertilizer. However, crop farmer's attention was at its use as fertilizer. The problem persisted after a little while as crop farmers brought the poultry waste only during cropping season, more so when they practice rain fed agriculture. This led to the idea of advising farmers to integrate vegetable production with their usual poultry farming. This solved the problem as the poultry farmers produced vegetables regularly using rain fed and irrigation practice. Ofuoku et al. (2011) found that the use of organic fertilizer is now common among farmers for soil conservation purpose. The vegetables are always in high yield and are sold for extra income. They are more advantageous during gestation periods when birds have not started producing eggs and meat.

The leaves are also fed to the birds as sources of minerals and vitamins to supplement their feeds. The leaf and the fruit vegetables also serve as source of food for the farm families. Consequently the money the farming household heads would have spent on the purpose of these vegetables for their families is saved and used for the procurement of other needs of their families. The money realized from crop farmers at the era when they sold the poultry droppings is expected not to be as much as what they realize since when they adopted the innovation and sold vegetables directly to consumers and also save money in the process as they may not spend money to procure needed vegetables for family use again.

The challenges facing them included high cost of pesticides and fungicides, Low market price of vegetables, pests and diseases infestation, high cost of improved vegetable seeds. The incidence of pests and diseases infestations have been indicted as the cause of an estimated annual yield loss of $25 \%$ of crop yields (FAO, 2001). This implies that pests and diseases- are two of the major causes of loss of vegetables. Narratives given by the farmers indicate that pests and diseases make them to spend extra money in the course of vegetable production, thereby increasing their cost of production, considering the high cost of pesticides and fungicides. Fungi diseases are the major diseases they contend with according to them. These fungi diseases have these pests as their vector insects.

They were of the opinion that the sales prices of vegetables in the market are two low. This is more so during the cropping season, however, they were of the opinion that it appreciates during the dry season when they practice irrigation in vegetable production. This means that what (the money) they could not make during the cropping season (raining season) is made by them during the dry season. 
The high cost of improved vegetable seeds is prompted just like in the case of pesticides and fungicides, by the fact that most improved vegetable seeds are imported since the output from the Nigeria Horticultural Research Institute is inadequate.

A few of the farmers were desirous of information on sources of improved seeds and horticultural practices. These ones, on observation are those who had not subscribed to membership of farmers' groups. As a consequence of the poor extension, farmer family ratio, extension interactions are carried out in specialized farmers' groups. Their failure to subscribe to membership of these groups has deprived them of access to information, ideas and extension advice.

Socioeconomic characteristics of the farmers such as sex, formal education, household size, farming experience, membership of farmers' groups and extension contact contributed to their level of adoption of integrated poultry-vegetable farming practice. Male poultry farmers are more likely to practice integration of poultry with vegetable farming. Ofuoku (2014) found that poultry farming in Delta State, Nigeria is male dominated. The male poultry farmers being household heads are more likely to practice the integrated farming in order to earn extra income and food source to cater for their households which form part of their responsibilities to their families. From observations men who are household heads always think of how to satisfy their households and raise their standard of living, hence their more involvement in the adoption of the innovative practice.

The higher the level of poultry farmers' formal education is, the more the likelihood of practicing the integration poultry-vegetable farming. This, according to Ofuoku and Albert (2014) is for the reason that education raises one's ability and attitude to inquire into the advantages associated with an innovation or idea. Madukwe (1995) suggests that education is one of the salient variables of adoption of farm practices. Education modifies human behavior and ways of reasoning. Having read and seen what the advantages are, formally educated farmers as innovators do not take long to adopt any innovation. Innovators are always intrinsically motivated to opt for change of practice, especially when the new practice is superior to the one they previously used. Innovators are not risk averse and they like experimenting and venturing into the use of new technologies.

Poultry farmers with large household sizes have more likelihood to practice poultry-vegetable integrated farming. This is attributable to the fact that the practice would contribute to the welfare of the household members. Footing the bills of a large household is a difficult task. In the presence of an opportunity of earning more of extra income will always be a welcome development for such farming household heads. The household head is expected and also expects himself to cater for the needs of his family, including relations as it is the culture in Africa. With such responsibilities staring at him, he becomes motivated to adopt integrated poultry-vegetable farming to earn more income that can contain his expenses towards his household and other relations.

The coefficient of membership of farmers' groups bore a negative sign. This implies that subscription to membership of farmers' group has the likelihood to towards not adopting integrated poultry-vegetable farming practice. The farmer's groups farm clearing houses for exchange of information and ideas among members. As a result of the dearth of extension agents, extension contacts with farmers are mostly done in groups. Groups also influence the behavior of individual members (Ogionwo and Eke, 1999). However, this result is at variance with a priori expectation. It is likely that some groups' members play dysfunctional roles in the group and always fail to pay attention to what is communicated to them. Many also do not see anything good coming out of ideas placed before them. Some also subscribe to membership of groups for other private reason other than farming related. This set of members finds such innovation irrelevant to them.

Increased contact of farmers with extension agents has the likelihood to raise the tendency to practice the integrated farming among poultry farmers. Ofuoku (2013), Asiabaka (2006) opine that frequency of extension contact with farmers increases the likelihood of adopting innovations and/or ideas. This means that the more contact extension agents have with farmers the lesser is the likelihood not to be influenced by the extension agents to exhibit a change in behavior. Frequency of contact between farmers and extension agents builds trust between them and this enhances believe in what in themselves and whatever transactions they have together. The healthy relationship between extension agents and farmers contributes to effectiveness of communication and extension teaching-learning process. This consequently leads to adoption of innovations and ideas communicated and taught to the farmers. 
Most of the farmers were young men who were also mostly married and had one level of formal education or the other. Most of them operated on small scale according to Nigerian standard. Majority of them had large household sizes with many years of farming experience. Most of them subscribed to membership of farmers' groups with 2 contacts with extension agents monthly. High levels of adoption of poultry - vegetable integrated farming was observed. They adopted the practice because of waste recycling, creation of extra income, feed for birds and vegetables for family consumption. The challenges they contended with ranged from high cost of improved vegetable seeds, pests and disease infestation, high costs of pesticides and fungicides, low market price of vegetables to inadequate information.

Their adoption level of poultry-vegetable integration farming was influenced by their sex, level of formal education, household size, farming experience, membership of farmers' groups and frequency of extension contact. Conclusively, their level of adoption of the practice was very encouraging, meaning that they responded well to the idea of poultry-vegetable integrated farming practice.

However, stemming from the challenges thay faced, it is recommended that the Delta State Agricultural Procurement Agency should be revived for the farmers to have access to cheap and improved vegetable seeds; pesticides and herbicides; extension agents should also introduce integrated pest management practice, which will reduce the cost of procurement of this input to them; extension agents need to teach them on the use of organic fungal control; and marketing extension which has been neglected also needs to be re-established to help farmers have access to markets where they will sell at prices that will be reasonable to them.

\section{Acknowledgements}

Our gratitude goes to the supportive staff of the Extension Unit of the Faculty of Agriculture of Delta State University. We also thank the poultry farmers used for this study for their kind cooperation and the vehicle drivers who took us to the various locations in the course of this study.

\section{References}

Adebayo, S. A., \& Adekunle, O. A. (2016). Socio-economic status of women in group membership in selected areas of Kwara State, Nigeria. Agrosearch 16 (1), 57- 64.

Adebolu, V.O \& Ikotun, S.J. (2001). Role of Research in Sustainable Fisheries Development Towards Poverty Alleviation in Nigeria. Proceeding of National Workshop for Agricultural and Rural Development in Nigeria. Jos, Nigeria, Pp. 21-33.

Aderinoye-Abdulwahab, S. A., \& Salami, S. T. (2017). Assessment of organic fertilizer usage by vegetable farmers in asa local government area of Kwara State, Nigeria. Agrosearch, 17(1), $101-114$.

Agbamu, J.U. (2011). Challenges and Prospects of Agricultural Extension in Nigeria. In Madukwe, M.C. (ed). Agricultural Extension in Nigeria, 216 - 229. Ilorin, Nigeria: Agricultural Extension Society of Nigeria.

Agbamu, J.U. (2011). Challenges and Prospects of Agricultural Extension in Nigeria. In Madukwe, M.C (ed). Agricultural Extension in Nigeria, 216-229. Ilorin, Nigeria: Agricultural Extension Society of Nigeria.

Almås, R., Bjorkhaug, H. \& Rivera-Ferre, M.G. (2011). Agriculture and climate change: introduction. International Journal of Sociology of Agriculture and Food, 18(3), 162-166.

Antti, P., Kortetmäki, T., Paloviita, A. \& järvelä, M. (2015). Social acceptance of climate change adaptation in farms and food enterprises: A case study in Finland. International Journal of Sociology of Agriculture and Food, 22( 2), 105-123.

Asiabaka, C.C. (1996). Factors Influencing the Adoption of Cassava Plant Protection Among Farmers in Nigeria. Benin: IITA and ESCAPP.

Byerlee, D., de Janvry, A. \& Sadoulet E. (2009) Agriculture for development: toward a new paradigm. Annual Review of Resource Economics, 1,15-31.

Council for Agricultural Science and Technology. (1999). Animal Agriculture and Global Food Supply. In Task Force Report, No. 135. Ames, lowa: CAST. 
Delgado, C., M. Rosegrant, H. Steinfeld, S. Ehui and C. Courbois. (1999). Livestock to 2020: The Nest Food Revolution. Food, Agriculture and the Environment Discussion Paper 28, Washington, D.C.: International Food Policy Research Institute.

Deressa, T. T., Hassan, R. M., Ringler, C., Alemu, T. \& Yusuf, M. (2009). Determinants of Farmers' Choice of Adaptation to Climate Change in Nile Basin of Ethiopia. Global Environmental Change.

DTADP. (2008). A Handbook on Poultry Famring. Asaba, Nigeria: Delta State Agricultural Development Programme.

FAO (2001). Bulletin of Statistics Rome, Italy: Food and Agriculture Organization.

Food and Agriculture Organization of the United Nations. (2000). Small Ponds Make a Big Difference: Integrating Fish with Crop and Livestock Farming. Rome: FAO.

Food and Agriculture Organization of the United Nations. (2001). Mixed crop-Livestock Farming: A Review of Traditional Technologies based on literature and Field Experience. Animal Production and Health Paper 152. Rome: FAO.

Food and Agriculture Organization of the United Nations. (2003). Integrated Livestock Fish Farming Systems. Rome: FAO.

Food and Agriculture Organization of the United Nations. (2007). Tropical Crop-Livestock Systems in Conservation Agriculture. The Brazilian Experience. Rome: FAO.

Foster, A. \& Rosenzweig, M. (2010). Microeconomics of technology adoption. Annual Review of Economics. 2, 395-424.

Hamidu, B.M., Murtala, N., Lliyasu, A.Y. \& Adamu, I.P. (2006). Assessment of adoption of afforestation innovations extension in DambataL. G.A of Kano State. Journal of Agricultural Extension, 4, 51-55.

Ibeawuchi, I.I., Okoli, N.A., Alagba, R. A., Ofor, M. O., Emma-Okafor, L. C., Peter-Onoh, C.A. \& Obiefuna, J.C., (2015). Fruit and vegetable crop production in Nigeria: the gains, challenges and the way forward. Journal of Biology, Agriculture and Healthcare, 5 (2), 21-28.

Karaturhan, B., Uzmay, A. \& Koc, G. (2018). Factors affecting the probability of rural women's adopting organic farming on family farms in Turkey. Ege Universitesi Ziraat Fakultesi Dergisi, 55(20, 153-160.

Madukwe, M.C. (1995). Obstacles to the adoption of yam miniselt technology by small scale farmers of South Eastern Nigeria. AGROSEARCH, 1(1), 1-5.

Ministry of Land and Survey (1991). Delta State Gazette. Asaba: Delta State Government.

Obi, F. O. Ugwuishiwu, B. O. \& Nwakaire, J. N. (2016). Agricultural waste concept, generation, utilization and management. Nigerian Journal of Technology, (35) 4, 957 - 964.

Ofuoku, A.U. (2011). Effect of Social Stratification on extension - farmer contact among poultry farmers in Delta State, Nigeria. Tropical Agricultural Research and Extension, 17 (384), 143152.

Ofuoku, A.U. (2013). Communication process and effectiveness of Agricultural Technology Messages in poultry production in Delta State, Nigeria. Ph.D thesis Postgraduate School, Rivers State, University of Science and Technology, Post Harcourt, Nigeria.

Ofuoku, A.U. (2013b). Willingness of farmers to participate in farmers' groups. Journal of Extension Systems, 29(1), 51-63.

Ofuoku, A.U. \&Albert, C.O. (2014). Conservation of traditional agricultural knowledge in Delta State, Nigeria. Social Change, 44(3), 401-412.

Ofuoku, A.U. \&Urang, E. (2012). Effect of cohesion on loan repayment in farmers' cooperative societies in Delta State, Nigeria. Agricultural-Science and Practice Journal, 3-4 (83-84), 131-139.

Ofuoku, A.U., Egbuchua, C \& Okonmah, L.U. (2011). A Tobit analysis of propensity to adopt soil conservation practices among arable crop farmers in Delta State, Nigeria. Agriculture - Science and Practice Journal, 1-2 (77-78), 10-18.

Ofuoku, A.U., Olele, N.F \& Emah, G.N (2008). Determinants of adoption of improved fish production technologies among fish farmers in Delta State, Nigeria. The Journal of Agricultural Education and Extension, 14(4), 297-306.

Ogionwo, W. \& Eke, P. (1999). An Introduction to Social Psychology. Owerri, Nigeria: Springfield Publishers.

Paarlberg, R. (2013). Food politics: What everyone needs to know? Oxford: Oxford University Press. 
Parveen, K. \& Nazhat, k. (2015). NGOs: A link between the rural women entrepreneurs and city dwellers. The Research Journal of Management Sciences, 4(3), 6-8.

Rehman, k., Ying, Z., Andleeb, S., Jiang, Z. \& Olajide, E. K. (2016). Short term influence of organic and inorganic fertilizers on soil microbial biomass and DNA in summer and spring. Journal of Northeast Agricultural University, 23(1), 20-27.

Stuart, T. (2009). Waste: Uncovering the Global Food Scandal. New York: W.W. Norton \& Company. Thiele, L.P. (2013) Sustainability. Cambridge: Polity Press Ltd.

Yonter, G. \& Uysal, H. (2018). Effects of humid substance on some erosion parameters of a sandy clay loam soil and pH and EC of drainage water. Ege Universitesi Ziraat Fakultesi Dergisi, 55(3), 299-304.

Yonter, G. \& Uysal, H. (2016). Tutin atiginin (serme ve karistirma) tin bunyeli bir topragin bazi erozyon parametreleri ve kimyasal ozellikleri uzerine etkilkeri. Ege Universitesi Ziraat Fakultesi Dergisi, 53(1), 19-24. 